\title{
Aging, Hearing Loss and Tinnitus
}

\author{
Marine Raquel Diniz da Rosa ${ }^{1 *}$, Daviany Oliveira Lima ${ }^{2}$, Mariana Lopes Martins ${ }^{1}$, Thaís Mendonça Maia Wanderley \\ Cruz de Freitas ${ }^{2}$ and Amanda Câmara Miranda ${ }^{3}$
}

${ }^{1}$ Department of Speech Language Pathology and Audiology, Federal University of Paraiba, Brazil

${ }^{2}$ Master Student of Speech Language Pathology and Audiology, Federal University of Paraiba, Brazil

${ }^{3}$ Master Student of Cognitive Neuroscience and Behavior, Federal University of Paraiba, Brazil

*Corresponding author: Marine Raquel Diniz da Rosa, Department of Speech Language Pathology and Audiology, Federal University of Paraiba, Brazil

\begin{abstract}
This article explores the occurrence of tinnitus and hearing loss in the elderly. Both are highly prevalent after 60 years old. It highlights the relationship between hearing loss, tinnitus and aging. And it points out some possible form of intervention.
\end{abstract}

\section{Introduction}

Since the end of the century, the number of elderly people worldwide has increased. By the year 2015 there will be about 2 billion people over the age of 60 . This population growth is probably due to the decline in the birth rate, improvement of socio-economic conditions of life and progress of modern medicine [1]. However, increasing longevity does not characterize good population health. As life expectancy progresses, there is also a greater number of chronic and incapacitating diseases, which must be properly monitored since they can cause problems for the quality of life of this population. Decreased functional capacity of organs and tissues is the main feature of aging and carries an increased risk of chronic degenerative diseases and declining status of the elderly in the family and in society. The gradual loss of physical energy and economic productivity tends to isolate and deprive of sources of information and communication [2].

However, some physiological changes that happen with the advancing age will only manifest itself from the third age. For example, the human ear reaches maturity around 18-20 years and from this age the hearing organ begins to age, either by loss of sensory cells, neurological degeneration, exposure to ototoxic agents or noise [3]. Hearing loss in the elderly, also known as presbycusis, is a bilateral hearing loss for high frequency sounds. The main clinical manifestations of presbycusis include symmetrical and slowly developing sensorineural hearing loss, high pitched tinnitus and speech recognition disorders [4]. In the case of presbycusis, generally, the hearing thresholds increase significantly between 70 and 80 years of age and reach another stable stage at high levels after 80 years of age, especially in high frequencies [5]. Tinnitus is a common complaint defined as a sound in the head or ears that occurs in the absence of any external acoustical source [6]. It may be caused by several conditions: otological, metabolic, neurological, orthopedic, cardiovascular, pharmacological, odontological and psychological, which in turn may be present concomitantly in the same individual [7]. It affects about $15 \%$ of the world population. It can occur at any stage of life, but the highest prevalence occurs in the elderly, probably due to deterioration of the auditory and vestibular systems $[8,9]$. Tinnitus is the second most common otorhinolaryngological complaint in the elderly [10], with tinnitus often more disturbing than hearing loss [11]. Approximately $33 \%$ of the elderly population is affected by tinnitus and $15 \%$ to $25 \%$ of them present interference with the quality of life caused by this symptom [12]. Both hearing loss and tinnitus can trigger important communication problems, which in turn lead to difficulties in social, occupational and family adaptation. It is very common for elderly individuals to report that they can hear but not understand speech. Some studies have attempted to identify the relationship between age, gender, hearing loss and tinnitus [13-15]; however, which not confirm that tinnitus discomfort could be explained by age, gender, and hearing loss. The hearing loss might be the most dangerous factor and if the its serious, the incidence of the tinnitus became higher. So, tinnitus in the elderly may be the result of a combination of factors. Therefore, other issues are likely to be investigated, such as psychological issues or underlying diseases. To date, is known 
that exist a high prevalence of hearing loss and tinnitus in the elderly, and that these have a high impact on the patient's quality of life. Becoming a factor of great negative repercussion for this population, hindering sleep, social life, concentration on daily and professional activities. The first step in care is to investigate the patient's history. A detailed anamnesis, which should address, in addition to questions about tinnitus, associated diseases, patient's lifestyle, diet, genetics, general health and the current effects of the disease on the patient's life. In addition to the anamnesis, the use of questionnaires is important in the evaluation of individuals with tinnitus, as it helps to confirm the presence of tinnitus and determines the severity of the symptoms $[16,17]$. Treatment may be based on direct reduction of severity or elimination of tinnitus, such as working with the patient's emotions in the face of tinnitus [18]. Other therapies also known are relaxation techniques, cognitive-behavioral therapy (CBT), psychological counseling, sound therapy, including hearing aids or sound generators, or a combination of these approaches [19]. Until now, CBT is the oneoff have scientific evidence for tinnitus treatment. However, when the patient has hearing loss and tinnitus, the Tinnitus Retraining Therapy has been demonstrating that this model of intervention becomes a treatment option for the relief of tinnitus in the elderly people [20] and of hearing aids could reduce the perception of tinnitus sound intensity and the bothersome with this symptom and with hearing loss [21].

\section{Conclusion}

In this way, neither hearing loss or tinnitus should be neglected, it is important found the better management and intervention that relieve the symptom of tinnitus and hearing loss. This can improve elderly quality of life.

\section{References}

1. (2017) United Nations Organization-UNO.

2. Papaléo Neto, Borgonovi (2002) Gerontologia: a vehicle e o envelhecimento em visão globalizada. São Paulo: Atheneu, pp. 124.

3. Costa SS, Cruz OL (1997) Oliveira JA. Otorrinolaringologia. Porto Alegre: Artes Médicas, pp. 51.

4. Mitchell P, Gopinath B, Wang JJ, Mc Mohan CM, Schneider J, et al. (2011) Five-year incidence and progression of hearing impairment in an older population. Ear Hear 32(2): 251-257.

5. Ji Fei, Lei Lei, Zhao Su Ping, Liu Ke Fang, Zhou Qi You, et al. (2011) An investigation into hearing loss among patients of 50 years or older Journal of Otology 6(1): 44-49.
6. Baguley D, McFerran D, Hall D (2013) Tinnitus. Lancet 382(9904): 16001607.

7. Lockwood AH, Salvi RJ, Burkard RF (2002) Tinnitus. N Engl J Med 347: 904-910.

8. Ahmad N, Seidman M (2004) Tinnitus in the Older Adult-Epidemiology, Pathophysiology and Treatment Options. Drugs and Aging 21(5): 297305.

9. Almeida LD, Mitre EI, Lemos L, Simões ECC (2005) Vestibulometria em indivíduos com zumbido e exames audiológicos normais. CEFAC 7(3): 382-387.

10. Lunedo SMC, Sass SMG, Gomes AB, Kanashiro K, Bortolon L (2008) Prevalência dos principals sintomas otorrinolaringológicos em uma população geriátrica ambulatorial. Arq Int Otorhinolaryngol 12(1): 9598.

11. Chang H, Chou P (2007) Presbycusis among older Chinese people in Taipei: Taiwan: a community-based study. Int J Audiol 46(12): 738-745.

12. Noroozian M, Jafari Z, Shahmiri E, Omidvar Sh, Zendehbad A, et al. (2017) Effect of Age, Gender and Hearing Loss on the Degree of Discomfort Due to Tinnitus. Basic and Clinical Neuroscience 8(6): 435-442.

13. Pinto PCL, Sanchez TG, Tomita S (2010) The impact of gender, age and hearingloss on tinnitus severity. Brazilian Journal of Otorhinolaryngology 76(1): 18-24.

14. Vanneste S, Joos K, De Ridder D (2012) Prefrontal córtex based sex differences in tinnitus perception: Same tinnitus intensity, same tinnitus distress, different mood. PLoS ONE 7(2): 31182.

15. Sanchez TG, Bento RF, Miniti A, Cârnara J (1997) Tinnitus: characteristics and epidemiology: experience at the Hospital das Clínicas. Brazilian Journal of Otorhinolaryngology 63 (3): 229-235.

16. Urnau D, Tochetto TM (2011) Características do zumbido e da hiperacusia em indivíduos normo-ouvintes. Arq Int Otorrinolaringol 15(4): 468-474.

17. Berberian AP, Ribas A, Imlau D, Guarinello AC, Massi G, et al. (2016) Benefit of Using the Prosthesis with Sound Generators in Individuals with Tinnitus Associated with Mild to Moderately Severe Hearing Loss. International Tinnitus Journal 20(2): 64-68.

18. Heijneman KM, Kleine M, van Dijk P 2012) A Randomized DoubleBlind Crossover Study of Phase-Shift Sound Therapy for Tinnitus. Otolaryngology Head and Neck Surgery 147(2): 308-315.

19. Hoare DJ, Gander PE, Collins L, Smith S, Hall DA (2012) Management of tinnitus in English NHS audiology departments: An evaluation of current practice. J Eval Clin Pract 18(2): 326-334.

20. Leandro SF, Mancini PC (2016) Zumbido crônico em idosos: uma proposta de intervenção. Estud interdiscipl envelhec Porto Alegre 21(3): 295-308.

21. Araujo TM, Iório MC (2016) Effects of sound amplification in self-perception of tinnitus and hearing loss in the elderly. Braz J Otorhinolaryngol 82(3): 289-296.

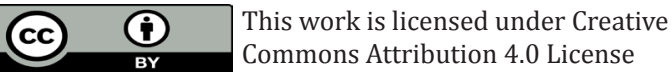

To Submit Your Article Click Here:

Submit Article

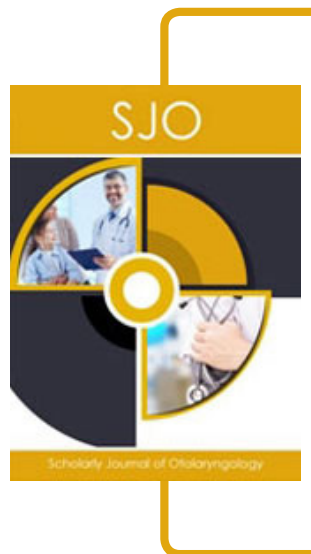

Scholarly Journal of Otolaryngology

\section{Assets of Publishing with us}

- Global archiving of articles

- Immediate, unrestricted online access

- Rigorous Peer Review Process

- Authors Retain Copyrights

- Unique DOI for all articles 